\title{
Stefnumörkun í heilbrigðismálum: leiðin til lýðheilsu
}

Karl Andersen¹ læknir, Vilmundur Guðnason² læknir

\section{ÁGRIP}

Langvinnir sjúkdómar eru algengasta orsök ótímabærra dauđ̌sfalla í heiminum og helsta ógn samtímans við efnahagslega og félagslega frampróun á pessari öld.1.,2 Pessir sjúkdómar eiga rót í óheilbrigðum lífsstíl, svo sem reykingum, óhollu mataræði, hreyfingarleysi og ofneyslu áfengis. ${ }^{3}$ Petta leiðir til háprýstings, offitu, sykursýki og langvinnrar lungnateppu svo dæmi séu tekin. Sýnt hefur verið fram á að með lýðgrunduðum inngripum má draga verulega úr helstu áhættupáttum langvinnra sjúkdóma meðal pjóðarinnar. ${ }^{4}$ Til pess parf markvissa stefnumörkun sem tekur mið af peim vísindalegu rökum sem fyrir liggja. Pannig má draga úr ótímabærum dauð̋söllum og veikindum af völdum pessara sjúkdóma.

Í pessari grein er fjallað um pólitíska stefnumörkun í heilbrigðismálum og hvernig nýta má hugmyndafræði atferlismótunar til pess að bæta lýdheilsu.
'Læknadeild Háskóla Islands, Hjartarannsókn og á Landspítala, ${ }^{2}$ læknadeild HÍ og Rannsóknarstöð Hjartaverndar.

Fyrirspurnir: Karl Andersen andersen@landspitali.is

Fyrri hluti pessarar greinar birtist í nóvemberblaðinu i haust: Andersen K, Guð̌nason V. Langvinnir sjúkdómar: heimsfaraldur 21. aldar. Læknablaðið 2012; 98: 591-5.

Greinin barst 14. febrúar 2013, sampykkt til birtingar

18. febrúar 2013.

Engin hagsmunatengs| gefin upp.

\section{Inngangur}

Flestar pjóðir heims standa frammi fyrir mikilli aukningu langvinnra sjúkdóma (Chronic Non-Communicable Diseases) á komandi áratugum. ${ }^{1,2}$ Sjúkdómar sem eiga rót í óheilbrigðum lífsstíl eru á góðri leið með að sliga heilbrigðiskerfi nútímans og verði ekkert að gert munu heilsufarslegar, félagslegar og efnahagslegar afleiðingar pessara sjúkdóma verða gríðarlegar. ${ }^{5}$ Faraldsfræðilegar rannsóknir hafa sýnt fram á tengsl nokkurra vel skilgreindra áhættupátta við langvinna sjúkdóma. Flestir eru pessir áhættupættir tengdir við óheilsusamlegan lífsstíl og pað má hafa áhrif á pá með aðgerðum sem móta lífsstílsákvarðanir fólks. ${ }^{3}$

Í flestum vestrænum löndum hefur dánartíðni vegna kransæðasjúkdóma lækkað á síðustu áratugum. Sýnt hefur verið fram á að stærsti hluti lækkunar dánartíðni skýrist af betri stöðu áhættupátta en minnihluti skýrist af meðferð sjúkdómsins. ${ }^{6-9}$

Pað skýtur pví skökku við að heilbrigðiskerfið er stílað inn á að meðhöndla sjúkdóma og pví að bregðast við bráðatilfellum. Lítill gaumur er gefinn að pví að viðhalda heilbrigði og fyrirbyggja sjúkdóma. Í Evópu fara tæplega $3 \%$ útgjalda til heilbrigðismála í forvarnir. Á Íslandi er hlutfallið hálfu lægra eða 1,6\% (mynd 1). En prátt fyrir ágætan árangur í meðferð margra bráðasjúkdóma skilja peir einstaklinginn eftir með skerta færni og langvinnt heilsutap. Sífellt fleiri ná pví að komast á efri ár en lifa síðustu æviárin með mikla byrði langvinnra sjúkdóma. Kostnaður samfélagsins er gríðarlegur, milli 70 og 80\% útgjalda til heilbrigðismála í Evrópu fara í umönnun langveikra og langvinnir sjúkdómar eru orsök $86 \%$ dauðsfalla í Evrópu. ${ }^{1,10}$ Til pess að viðhalda heilbrigði sem flestra og stuðla að öldrun án langvinnra sjúkdóma parf að beita forvarnaraðgerðum sem byggjast á lýðgrunduðum inngripum samhliða áhættuskimun. ${ }^{11,12}$

\section{Pólitísk úrræði}

Forvarnir sem beinast að pjóðinni (lýðgrunduð inngrip) eru pess eðlis að pær krefjast almennt pólitískra aðgerða. Hér hafa læknar og annað fagfólk mikilvægu hlutverki að gegna í pví að miðla vísindalegri pekkingu og ráðgjöf til peirra sem hafa valist til pess að móta pað umhverfi sem við búum i. $^{13}$ Stjórnmálamenn verða fyrir prýstingi margra hagsmunahópa við ákvarðanatöku, til dæmis landbúnaðar, matvælaiðnaðar, tóbaksiðnaðar,

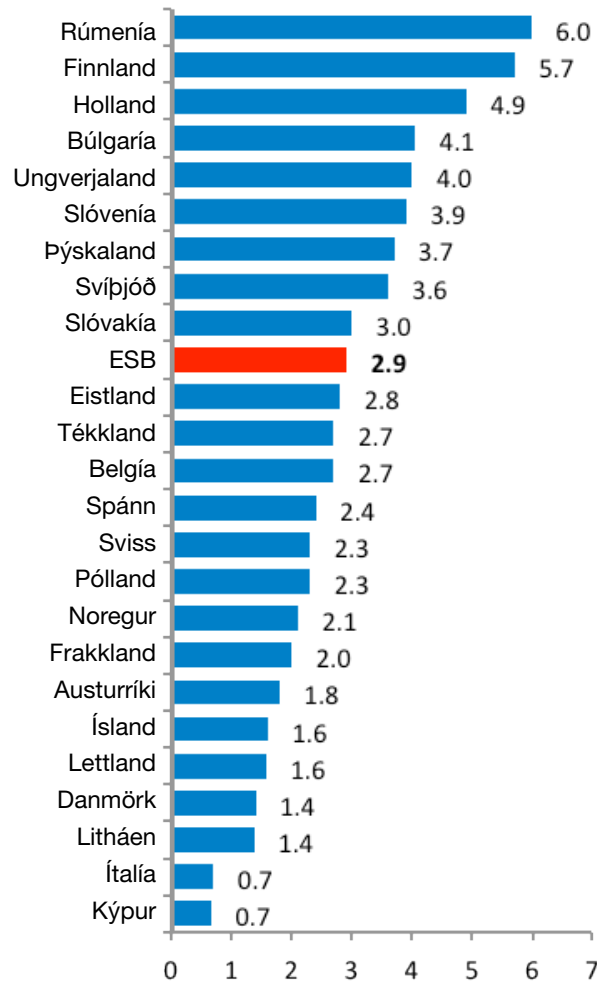

Mynd 1. Hlutfall útgjalda til heilbrigðismála sem varið er í forvarnir. Heimild: OECD Health Data 2010; Eurostat Statistics Database. 
lyfjaiðnaðar, heilbrigðisstarfsfólks, sjúklingasamtaka, foreldra og almennings. Pólitísk inngrip eru nauðsynleg til pess að ná árangri en pau verða að vera byggð á upplýstri ákvarðanatöku fremur en hagsmunagæslu prýstihópa. Hér geta hagsmunir augljóslega rekist á. Hagsmunir matvælaiðnaðar eru til dæmis ekki endilega í samræmi við manneldismarkmið sem byggja á pví að draga úr neyslu mettaðrar fitu og sykurs. Um $75 \%$ af öllu pví salti sem við neytum kemur úr tilbúnum matvælum en einungis fjórðungi er bætt í við matseld eða við matarborðið. Saltneysla á dag er um pað bil tvöfalt til prefalt pað magn sem mælt er með (6-7 g/dag) og hefur mikil áhrif til hækkunar á meðaltalsblóðprýstingi meðal pjóðarinnar. ${ }^{14-17}$ Matvælaiðnaðurinn hefur pví umtalsverð áhrif á pað hvort við borðum heilnæma fæðu eða ekki. Nauðsynlegt er að stjórnvöld hafi eftirlit með og setji regluverk um framleiðslu tilbúinna matvæla. Á pað bæði við um innihald salts, sykurs og mettaðrar fitu. Рó að neytandinn beri sjálfur ábyrgð á pví hvaða matvöru hann velur í verslun eða veitingahúsi getur verið erfitt fyrir hann að gera sér grein fyrir pví af merkingum eða matseðli hvort unnin matvæli stuðli að háum blóðprýstingi eða hækkun á kólesteróli í hverju einstöku tilviki. Рað sem skiptir pó meira máli eru áhrifin sem tilbúin matvæli hafa á stöðu áhættupátta að meðaltali hjá pjóđinni allri. Hér er ábyrgðin ekki einstaklingsins, heldur verða stjórnvöld að hafa eftirlit með og setja reglugerð um innihald tilbúinna matvæla. Með neyslustýringu geta stjórnvöld dregið úr neyslu óhollra fæðutegunda en aukið í staðinn neyslu ávaxta og grænmetis. ${ }^{18}$ Petta hefur til dæmis verið gert með sérstökum sykurskatti með pað аð markmiði að draga úr heildarneyslu sykraðra gosdrykkja og annarrar matvöru með miklum viðbættum sykri. Óhófleg neysla sykurs stuðlar að peim offitufaraldri sem flest lönd búa við í dag. Offita og afleidd sykursýki er ein helsta undirrót margra langvinnra sjúkdóma. •að er pví lýðheilsumarkmið að draga úr sykurneyslu pjóðarinnar til að stemma stigu við pessari sjúkdómspróun. Pessi sykurskattur hefur verið gagnrýndur, ekki síst af matvælaiðnaðinum, og er gott dæmi um pað hvernig almannahagsmunir og hagsmunir einkageirans geta rekist á. Sýnt hefur verið fram á að við neyslustýringu er skattlagning óhollustu mun áhrifameiri aðferð en afslættir eða niðurgreiðsla á hollari matvöru par sem fólk leitast almennt við að draga úr fjárhagslegu tjóni (loss aversion). ${ }^{19}$

Annað vel heppnað inngrip er takmörkun á notkun transfitusýra í matvælaiðnaði. Pessi tegund fitusýra sem verður til við hýdroxýleringu ómettaðrar fitu, til dæmis við upphitun mjúkrar ómettaðrar fitu, hefur reynst stuðla að æðakölkunarsjúkdómi. ${ }^{20-22}$ Раð er nokkurn veginn ómögulegt fyrir neytandann að gera sér grein fyrir pví hvort hann er að neyta transfitusýruríkra matvæla pví að pessi tegund fitu er bæði bragð- og lyktarlaus. Bann við notkun transfitusýra í matvælaiðnaði hefur nánast útrýmt pessari auknu hættu og er dæmi um vel heppnað inngrip stjórnvalda eftir ábendingar fagfólks í heilbrigðisstétt. ${ }^{21}$ Inngripið kostar nánast ekkert en sparar nokkra tugi mannslífa á hverju ári á Íslandi. Ísland var fjórða landið í Evrópu til að taka upp slíka löggjöf, næst á eftir Dönum, Svisslendingum og Austurríkismönnum. ${ }^{20,22}$

Nærtækasta dæmi um pólitísk inngrip sem hafa skilað árangri er pó bann við reykingum á opinberum stöðum. Fyrsta pjóðin í Evrópu til að taka upp slíkt bann voru Írar árið 2004, en fljótlega eftir pað fylgdu Englendingar, Íslendingar og fleiri í kjölfarið. Alls staðar par sem slíkt bann hefur verið innleitt hefur tilfellum kransæðastíflu fækkað um 17-19\% innan nokkurra vikna, bæði meðal reykingamanna og hinna sem ekki reykja. ${ }^{23-25}$ Pessi löggjöf, sem í fyrstu var sett til að bæta vinnuumhverfi peirra sem ekki reykja, varð pannig að mjög áhrifamiklu lýðheilsulegu inngripi.

Árangursríkasta leiðin til að stemma stigu við faraldri langvinnra sjúkdóma er að beita pólitískum inngripum sem miða að pví að koma í veg fyrir próun sjúkdóma, með pví að móta pað umhverfi sem við búum í. Slík inngrip eru bæði fljótvirk og hagkvæm og skila betri árangri í lýðheilsu en meðferð sjúkdóma. ${ }^{12,26}$

\section{Stefnumörkun á alpjódavettvangi}

Á leiðtogafundi allsherjarpings Sameinuðu pjóðanna í september 2011 var pví beint til aðildarlanda að móta stefnu um forvarnir langvinnra sjúkdóma og skila árangursskýrslu fyrir næsta ping árið 2014. ${ }^{27}$ Helstu áherslupættir í pessari vinnu eru eftirfarandi:

\section{Tóbaksvarnir}

Að framfylgja rammaáætlun Alpjóðaheilbrigðismálastofnunarinnar, WHO, um tóbaksvarnir frá 2003 (Framework Convention on Tobacco Control, FCTC). ${ }^{28}$ Í pessu felst meðal annars að samræma og auka skatta og smásöluálagningu á tóbaki til pess að draga úr neyslu pess. Að takmarka aðgengi ungmenna að tóbaki og minnka sýnileika pess með pví að banna tóbaksauglýsingar og kostun tóbaksfyrirtækja á ípróttakappleikjum. Að innleiða bann við sölu tóbaks á internetinu og í sjálfsölum. Rétt er að benda á að í rammaáætluninni er ekki gerður greinarmunur á reyktóbaki og reyklausu hvað petta varðar. Mælt er með að aðildarlönd taki upp reglugerð sem bannar tóbaksreykingar á opinberum stöðum. Petta hefur víðast leitt til pess að fækka tilfellum hjartaáfalla um 17-19\%. Аð gera skylt að merkja tóbak með upplýsingum og varnaðartexta um skaðsemi reykinga, að fjarlægja öll vörumerki af tóbakspökkum og selja pessar vörur í stöðluðum einsleitum brúnum pakkningum. Íslendingar hafa nú pegar uppfyllt flest ákvæði rammaáætlunar um tóbaksvarnir. Pannig hefur bann við tóbaksauglýsingum verið í gildi á Íslandi um margra ára skeið og hefur stuðlað að pví að reykingamönnum hefur fækkað um meira en helming á síðasta aldarfjórðungi. Pessi fækkun reykingamanna skýrir um $22 \%$ af peirri fækkun ótímabærra dauðsfalla vegna kransæðastíflu sem varð á Íslandi á árunum 1981-2006. ${ }^{6}$ Рað er pó full ástæða til að vera á varðbergi gagnvart peirri markaðssetningu á reyklausu tóbaki sem beinist að ungu fólki í dag. Fullyrðingar um að munntóbak sé skaðlaust heilsunni minna ópægilega á andvaraleysið við markaðssetningu reyktóbaks um miðja síðustu öld.

\section{Mataræði}

Stefna ber að pví að draga úr notkun salts í tilbúnum matvælum pannig að heildarneysla salts fari niður fyrir $5 \mathrm{~g}$ á dag. Að taka upp merkingarkerfi á tilbúnum matvælum sem gerir neytendum kleift að lesa upplýsingar um innihald salts, fitu og næringarefna í tilbúnum matvælum. Að heildarinntaka mettaðrar fitu fari ekki yfir $10 \%$ af heildarorkuneyslu á dag. Að draga verulega úr eða koma í veg fyrir notkun transfitu í tilbúnum matvælum. Að tryggja að í lögum og reglugerðum um landbúnað og matvælaframleiðslu séu áhrif á hollustu og heilbrigði höfð að leiðarljósi. Takmarka ber auglýsingar á óhollum mat- og drykkjarvörum sem beinast að börnum, sérstaklega í sjónvarpi og netmiðlum. Í pessum efnum eigum 
við Íslendingar enn nokkuð langt í land, sérstaklega við merkingar matvæla og takmörkun á notkun salts í matvælaframleiðslu. ${ }^{18}$

\section{Áfengi}

Að auka og samræma skattlagningu áfengis til að draga úr neyslu pess. Að takmarka aðgengi ungmenna að áfengi og banna áfengisauglýsingar. Að koma á framfæri upplýsingum um skaðleg áhrif af ofnotkun áfengis, sérstaklega á lifrarsjúkdóma, geðsjúkdóma og pau félagslegu vandamál sem af áfengisneyslu geta hlotist. Hér hafa Íslendingar löggjöf sem tryggir pessa pætti en engin rannsókn hefur farið fram á árangri pessarar lagasetningar.

\section{Umhverfi}

Auka ber möguleika á pví að ferðast bíllaust til og frá vinnu, með pví að skipuleggja borgir með peim hætti að auðvelda hjólandi og gangandi umferð á kostnað einkabíla. Að tryggja opin svæði og möguleika almennings til hreyfingar og ípróttaiðkunar án pess að vera meðlimur í ípróttafélögum. ${ }^{29,30}$ Dæmi um petta eru opinberir sundstaðir og sparkvellir með frjálsu aðgengi fyrir almenning. Við skipulagningu opinberra bygginga, verslunar- og pjónustuhúsnæðis mætti gera ráð fyrir að notaðir séu stigar til að komast á milli hæða fremur en lyftur og rúllustigar. ${ }^{29,30}$

\section{Heilbrigði í allri stefnumörkun}

Lýðheilsa og forvarnir gegn langvinnum sjúkdómum takmarkast ekki við íhlutanir á sviði heilbrigðismála eingöngu. Stefnumörkun á sviði menntamála, landbúnaðar, matvælaframleiðslu, efnahagsmála, verslunar og pjónustu hefur allt bein eða óbein áhrif á próun langvinnra sjúkdóma í samfélaginu. Pess vegna er nauðsynlegt að við alla stefnumörkun sé gætt peirrar grundvallarforsendu að hagsmunir heilbrigðis séu ekki fyrir borð bornir. Dæmi um petta er til dæmis pegar niðurskurður til menntamála leiðir til pess að kennsla í ípróttum er skert í námsskrá grunnskóla. Skipulag borga með tilliti til gangandi og hjólandi umferðar og opinna útivistarsvæða er annað dæmi par sem hagsmunir einkaaðila og samfélagsins geta rekist á. Framleiðsla og verðlagning landbúnaðarafurða tekur ekki nægjanlega mið af peim markmiðum sem sett hafa verið í manneldismálum. Verðlagning hollra matvæla, ávaxta, grænmetis og fisks ætti að vera með peim hætti að pessar matvörur væru bæði ódýrari og aðgengilegri en óhollur skyndibiti og sælgæti. Í flestum ípróttahúsum, skólum og sjúkrahúsum landsins má finna sjálfsala par sem kaupa má gos og sælgæti en ávexti er par hvergi að finna. Til pess að breyta pessu parf pverfaglega nálgun par sem lýðheilsa er ekki eingöngu á ábyrgð yfirvalda í heilbrigðismálum heldur samfélagsins í heild, bæði stjórnvalda, opinberra aðila, hagsmunasamtaka og einkageirans.

\section{Heilbrigði sem fyrsta val}

Раð sem ræður pví hversu útsett við erum fyrir langvinnum sjúkdómum eru nokkrir vel skilgreindir áhættupættir eins og rakið var í fyrri grein okkar. Að hluta til ákvarðast pessir áhættupættir af pví umhverfi sem við búum í og er utan við pað sem við höfum sem einstaklingar stjórn á. Dæmi um petta eru reykingar á opinberum stöðum, transfitusýrur í tilbúnum matvælum, loftmengun og fleira. Á hinn bóginn er lífsstíll eða frjálst val einstaklingsins sem ákvarðar til dæmis hvort hann byrjar að reykja, hreyfir sig reglulega eða borðar hollan mat. En val er ekki eins frjálst og margir halda. Flestir peir sem reykja á fullorðinsárum byrjuðu til dæmis að reykja sem börn eða unglingar, langt fyrir sjálfræðisaldur og hafa síðar ánetjast fíkninni, pannig að peir geta ekki hætt að reykja. Раð er pví í fæstum tilfellum frjálst val sjálfráða einstaklings sem ræður pví hvort fólk reykir eða ekki. Margar af peim ákvörðunum sem við tökum í daglega lífinu eru teknar í fljótfærni vegna pess að valið hefur á einn eða annan hátt verið tekið fyrir okkur (default option). ${ }^{31}$ Dæmi um petta er hvernig vörum er stillt upp í verslunum. Sælgætishillur við búðarkassann auka sölu sælgætis en ef ávextir væru í boði í staðinn mundi pað hafa jákvæð áhrif á neyslu peirra. ${ }^{32}$ Sömu sögu er að segja um tóbak. Par sem tóbak er sýnilegt bak við búðarborð er meira selt af tóbaki. Við teljum okkur trú um að við ákveðum sjálf hvaða vöru við veljum en í raun er pað að miklu leyti háð úthugsaðri markaðssetningu og pví hvernig vörum er raðað í hillur verslana. Aðgengi að vöru og pjónustu og öflug markaðssetning hefur pannig mun meiri áhrif á hegðunarmynstur okkar en við höldum. Börn eru sérstaklega útsett fyrir neyslustýringu af pessu tagi og parf að vernda sérstaklega. Hjartavernd hefur tekið pátt í alpjóðlegu rannsóknarverkefni á vegum Evrópusamtaka hjartaverndarfélaga (European Heart Network) um markaðssetningu á matvælum frá árinu 2004 par sem sérstaklega er kannað hvaða áhrif auglýsingar sem beinast að börnum hafa á offitu á meðal peirra.

\section{Atferlishagfræði}

Til pess að ná árangri með lýðgrunduðum inngripum er gagnlegt að taka mið af kenningum atferlishagfræði (behavioral economics). Pessi fræðigrein á rætur bæði í sálfræði og hagfræði og skilgreinir atferli fólks pegar pað stendur frammi fyrir valkostum, meðal annars í sambandi við heilsu. ${ }^{33}$ Hér á eftir verða rakin nokkur hugtök úr pessari fræðigrein og tekin dæmi um hvernig hún getur komið að gagni við lýðgrunduð inngrip í lýðheilsu. ${ }^{33}$

\section{Tvenns konar ákvarðanataka}

Samkvæmt Nóbelsverðlaunahafanum Daniel Kahneman stjórnast val okkar og hegðun af tveimur aðskildum kerfum. ${ }^{34}$ Fyrra kerfið sem kalla má innsæi einkennist af hraðri ákvarðanatöku, óigrundaðri og ómeðvitaðri, sem byggir oft á tilfinningu frekar en rökhugsun. Í síðara kerfinu byggir ákvarðanataka á rökhugsun, meðvituðu mati á kostum og göllum, hún er hægvirkari og útheimtir meiri athygli. Pessi tvö kerfi koma bæði við sögu í daglegum ákvörðunum fólks, til dæmis varðandi val á neysluvöru. Flestar ákvarðanir sem teknar eru í flýti, undir álagi eða í streituvekjandi umhverfi fylgja fyrra kerfinu. Petta á við um val á matvöru í verslunum til dæmis. Rannsóknir hafa sýnt að einföld skilaboð um næringarinnihald, til dæmis með umferðarljósakerfi, eru mun áhrifaríkari en nákvæmar töflur um innihald fjölmargra næringarefna. Tóbaksframleiðendur og skyndibitakeðjur notfæra sér pessa hugmyndafræði í markaðssetningu sinni. Нöfðað er til huglægra pátta, svo sem gleði, hamingju og vellíðunar pegar pessar vörur eru auglýstar, og pær eru settar fram á pann hátt að „valið“ að kaupa pær verði tekið í flýti, óígrundað og ómeðvitað. Dæmi um petta eru tóbak og sælgæti við búðarkassann í matvöruverslunum, skyndibitastaðir við pjóðveginn og sælgætissjálfsalar 
á sundstöðum og skólum. Inngrip lýðheilsunnar hafa fram til pessa byggt meira á seinna kerfinu, pví sem byggist á rökhugsun, og eru par af leiðandi ekki eins áhrifarík. Dæmi um petta eru merkingar matvæla út frá innihaldi ýmissa næringarefna, reiknað út frá dagspörf, sem parf talsverða kunnáttu og tíma til að geta nýtt sér. Upplýsingar og áróður um skaðsemi reykinga er annað inngrip sem reynir að draga úr reykingum með pví að höfða til rökhugsunar en sú aðferð kemur ekki að sama gagni og hin sem torveldar óígrundaða ákvörðunartöku með pví að takmarka aðgengi að tóbaki (gera pað minna sýnilegt í verslunum) eða tóbaksreyk (með pví að banna reykingar á opinberum stöðum).

\section{Hugsunarlaust át}

Ytri aðstæður hafa sömuleiðis áhrif á neysluvenjur okkar. Sýnt hefur verið fram á að stærð mataríláta hefur mikil áhrif á skammtastærðir og hversu mikið fólk borðar ómeðvitað. Ef matardiskar eru stórir borðar fólk ómeðvitað meira. ${ }^{35}$ Par sem ofurskammtar eru eðlilegur valkostur (default) er erfitt að gæta hófs í mataræði. Niðurstaðan verður ofneysla, offita og afleiddir sjúkdómar. Petta hefur verið kallað „,mindless eating“ sem má útleggja sem hugsunarlaust át. ${ }^{36,37}$ Rannsóknir hafa sýnt að draga má úr ofneyslu og beina henni í heilsusamlegri farveg með pví að setja fram heilbrigðari valkosti sem fyrsta val (default), til dæmis í skemmtigörðum, á matseðlum veitingahúsa eða í mötuneytum. ${ }^{37,38}$

Hegðun okkar mótast meira af ávinningi í nútíð en tapi í framtíð. Til dæmis er ánægja af sælgæti eða sígarettu núna mun sterkari áhrifamáttur á hegðun en sú vitneskja að slík neysla leiði af sér skaða í framtíðinni. ${ }^{39}$ Inn í petta blandast einnig að fólk hefur tilhneigingu til að vanmeta kerfisbundið eigin áhættu í samanburði við aðra, sem kallað hefur verið „optimism bias“ eða bjartsýnisbjögun. ${ }^{40}$ Pó að pað sé vel pekkt staðreynd að helmingur reykingamanna deyi af völdum reykingatengdra sjúkdóma (fyrst og fremst krabbameins, hjarta- og heilaáfalla) gera fæstir reykingamenn ráð fyrir að petta eigi við um pá sjálfa.

\section{Bod og bönn}

Í hugum margra Vesturlandabúa eru pau inngrip sem að ofan eru rakin talin vega að sjálfsákvörðunarrétti fólks og peirra almennu mannréttinda að fá að ákveða sjálfur hvaða neyslumynstur og lífsstíl hver og einn velur sér. Í ljósi pess sem rakið er hér að ofan er petta pó ekki alveg svona einfalt. Við treystum á opinbera eftirlitsaðila til að fylgjast með pví að vörur og pjónusta sem við kaupum séu ekki skaðleg heilsu okkar. Við viljum geta gengið út frá pví að vara hafi staðist alpjóðlegar gæðaprófanir áður en hún ratar í hillur verslana. Við viljum geta treyst pví að iðnaðurinn losi ekki mengunarvaldandi efni út í umhverfi okkar pannig að við bíðum heilsutjón af. Á sama hátt parf að vernda okkur og pá sérstaklega börn og unglinga fyrir harðsvíraðri markaðssetningu og auglýsingum sem miða að pví að auka neyslu okkar á vörum sem valda okkur heilsutjóni. Рað er til dæmis óhugsandi að hver og einn neytandi geti tileinkað sér nægilega pekkingu á næringarfræði til að meta sjálfur hvaða heilsufarsleg áhrif matvæli î neytendapakkningum hefur. Fæstir gera sér grein fyrir raunverulegum afleiðingum tóbaksreykinga á heilsu reykingamannsins og peirra sem eru útsettir fyrir óbeinum reykingum. Kostnaður samfélagsins er sömuleiðis gríðarlegur. Að pessu athuguðu má færa rök fyrir pví að boð og bönn, til dæmis við áfengis- og tóbaksauglýsingum, eigi rétt á sér. Pess vegna hefur pví verið haldið fram að sú hugmyndafræði sem lítur á boð og bönn (nanny state) sem neikvæð afskipti af sjálfsákvörðunarrétti einstaklingsins eigi ekki við pegar kemur að hollustuvernd og lýðheilsu. ${ }^{41}$

\section{Ójöfnuður eykur óheilbrigð̇i}

Рað er vel pekkt staðreynd að peir sem standa höllum fæti í efnahagslegu eða félagslegu tilliti búa við lakari heilsu en hinir sem betur eru settir. ${ }^{42,43}$ Petta á jafnt við innan pjóða og milli landa. pau lönd sem verja minnstu til félagslegs jöfnuðar búa við mestu gjá í heilbrigði milli ríkra og fátækra. Til pess að bjóða öllum sambærilega möguleika til heilbrigðs lífs parf að vera til staðar félagslegt stuðningsnet sem býðst öllum, óháð efnahag eða stöðu í pjóðfélaginu. Aðgerðir sem bæta lýðheilsu og vinna gegn langvinnum sjúkdómum leiða til ávinnings fyrir samfélagið í heild par sem pær draga úr fjarvistum frá vinnu, framleiðnitapi og auka skatttekjur um leið og pær létta á útgjöldum í heilbrigðiskerfinu. Nýleg íslensk rannsókn sýndi að um 22\% fullorðinna frestuðu eða felldu niður læknispjónustu á 6 mánaða tímabili og voru bágur efnahagur og langvinnir sjúkdómar meðal peirra pátta sem réðu pví að peir frestuðu læknisheimsókn. ${ }^{44}$

\section{Mælingar og árangursmat}

Samanburður á faraldsfræðilegum gögnum milli landa byggist á samræmdri skráningu. Áhrif inngripa verða ekki metin nema slík gagnavinnsla sé markviss og stöðug yfir tíma. Mikilvægt er að samræma skráningu lýðheilsufræðilegra gagna til að auðvelda pennan samanburð. ${ }^{45}$ Íslendingar standa vel að vígi vegna framsýni manna sem lögðu grunn að faraldsfræðilegum rannsóknum eins og rannsóknum Hjartaverndar og Krabbameinsskrá Krabbameinsfélagsins. Í mörgum tilvikum er hins vegar ekki um slembiraðaða rannsóknaraðferð að ræða pegar áhrif inngripa eru metin, heldur treyst á afturskyggnt rannsóknarsnið. Til dæmis má nefna áhrif af falli kommúnismans á dauðsföll vegna hjarta- og æðasjúkdóma í Póllandi. Fyrir 1990 voru niðurgreiðslur á landbúnaðarafurðum með peim hætti í Póllandi að bændur fengu greitt fyrir framleiðslu á feitu kjöti. Við fall kommúnismans 1991 hættu pessar niðurgreiðslur en landið opnaðist um leið fyrir innflutningi á grænmeti og ávöxtum. Dánartíðni vegna hjarta- og æðasjúkdóma sem hafði stigið hratt á tíma niðurgreiðslukerfisins snerist við og hefur síðan farið lækkandi. ${ }^{46}$

\section{Evrópusamtök gegn langvinnum sjúkdómum}

Árið 2010 höfðu samtök evrópskra hjartalækna (European Society of Cardiology, ESC) forgöngu um að kalla saman félagasamtök sem vinna hvert á sínu sviði gegn langvinnum sjúkdómum í Evrópu. Mönnum varð fljótlega ljóst að til pess að ná árangri í baráttunni gegn langvinnum sjúkdómum var mun árangursríkara að bindast samtökum og tala einum rómi en að vinna hver í sínu horni. Með pví móti má ná eyrum heilbrigðisyfirvalda á mun markvissari hátt. Petta skýrist ekki síst af pví að Evrópusambandið hefur ekki áhuga á að vinna gegn einstökum sjúkdómum, heldur líta pau á sjúkdómaflokka eða langvinna sjúkdóma sem eina heild. Pannig 
Tafla I. Mælanleg markmið sett fram af Evrópusamtökum gegn langvinnum sjúkdómum.

- Fækkun dauðsfalla vegna langvinnra sjúkdóma um 25\% fyrir árið 2025

- Fækkun reykingamanna í minna en 5\% fyrir 2040.

- Draga úr meðal saltneyslu í minna en 5 g/dag fyrir árið 2025.

- Draga úr neyslu mettaðrar fitu í minna en $10 \%$ af daglegri orkuneyslu fyrir 2025.

- Útrýma notkun transfitusýra í matvælaframleiðslu fyrir 2025.

- Minnka um helming neyslu sykurs í matvælum og drykkjarvöru fyrir 2025.

- Innleiða varnaðartexta á alla áfenga drykki.

- Draga úr sölu og neyslu áfengis um $10 \%$ og fækka lifrarsjúkdómum tengdum áfengi um 10\% fyrir 2025.

- Veita peim sem hafa langvinna sjúkdóma eđa eru í aukinni áhættu að próa slíka sjúkdóma ódýr, örugg, áhrifarík lyf, bóluefni og önnur meðferðarúrræði sem við eiga.

- Stöðva núverandi fjölgun tilfella af sykursýki.

er áherslan innan ESB á að viðhalda heilbrigði (health promotion) í víðum skilningi miklu fremur en á forvarnir einstakra sjúkdóma (disease prevention) en á pessu tvennu er gerður skýr greinarmunur. Læknar og aðrar heilbrigðisstéttir sem vinna á hinum pólitíska vettvangi verða аð læra pennan hugsanagang og skilja hvernig ákvarðanir eru teknar innan Evrópusambandsins til pess að ná árangri. Fyrir okkur Íslendinga skiptir ekki máli hvort við erum innan eða utan Evrópusambandsins að pessu leyti. Sú samleið sem við eigum með peim pjóðum sem par eru er augljós og pví tökum við pátt í pessari vinnu og peirri baráttu sem par fer fram. Frá stofnun Evrópusamtaka gegn langvinnum sjúkdómum (European Chronic Disease Alliance) árið 2010 hefur mikil vinna farið í að vekja athygli einstakra pingmanna Evrópupingsins og leiðtogaráðs ESB (European Council) á vísindalegum rökum fyrir forvörnum langvinnra sjúkdóma. Megináherslan í pessu starfi hefur verið að byggja röksemdafærsluna á traustum vísindalegum grunni og sýna fram á að inngrip á grundvelli lýðheilsu eru ódýr, fljótvirk og mjög áhrifarík í pví að draga úr sjúkdómum og viðhalda heilsu (tafla I). Með pví að beita ódýrum inngripum sem hafa jákvæð áhrif á heilsufar alls almennings má draga verulega úr sjúkdómsbyrði, ójöfnuði og útgjöldum til heilbrigðismála. Petta starf að lýðheilsu hefur oft og tíðum mætt mikilli andstöðu hagsmunaaðila, til dæmis tóbaksiðnaðar, matvælaiðnaðar og landbúnaðar, en einnig frá samtökum innan einkageirans, svo sem samtökum sjónvarpsstöðva, verslunar og pjónustu. Prátt fyrir petta hefur Evrópusamtökum gegn langvinnum sjúkdómum orðið verulega ágengt í málflutningi sínum og náð að koma sjónarmiðum sínum á framfæri við heilbrigðisyfirvöld í Evrópusambandinu og í einstökum aðildarríkjum pess. ${ }^{47,48}$

\section{Álitamál}

Hugmyndafræði lýðheilsu og forvarnaraðgerðir mæta oft mikilli andstöðu meðal almennings. Margir líta á pað sem forsjárhyggju og takmörkun á sjálfsákvörðunarrétti einstaklingsins pegar reynt er að stuðla að heilbrigði með peim aðferðum sem hér hafa verið raktar. Pó er enginn ágreiningur um að setja lagaramma utan um mengun umhverfis, geislavarnir, verndun hreins drykkjarvatns og lofts. Mikil umræða verður um loftmengun vegna sorpbrennslustöðva og bálkasta um áramót. Áhrif pessara hluta á heilbrigði landsmanna er pó hverfandi í samanburði við pá áhættupætti langvinnra sjúkdóma sem hér hafa verið til umfjöllunar. Ef áhrif óheilsusamlegs mataræðis, tóbaksnotkunar og hreyfingarleysis eru borin saman við áhættuna sem skapast til dæmis af geislavirkum úrgangi verður mönnum betur ljóst að um raunverulega og fyrirbyggjanlega áhættupætti er að ræða sem sjálfsagt er að stemma stigu við með stjórnvaldsaðgerðum í samvinnu við fagfólk og hagsmunaaðila.

Faraldsfræðilegar rannsóknir sýna óumdeilanlega samband milli vissra áhættupátta og próunar langvinnra sjúkdóma. Рað sem faraldsfræðilegar rannsóknir geta hins vegar ekki gert er að sanna að orsakasamband sé á milli áhættupáttar og sjúkdóms. Til pess parf slembiraðaða rannsókn (randomized clinical trial) með aðferðum gagnreyndrar læknisfræði (evidence based medicine). Раð er oftast illframkvæmanlegt að beita slembiröðuðum rannsóknaraðferðum í lýðheilsurannsóknum. Annars vegar vegna pess að pá parf að rannsaka gríðarlega stóran hóp fólks með ærnum tilkostnaði og sömuleiðis parf að bíða í langan tíma eftir pví að mælanlegur sjúkdómur komi fram. Mjög erfitt er að framkvæma slembiraðaðar rannsóknir á atferli fólks, til dæmis mataræði eða hreyfingu, pví margir munu ekki fylgja mataræðisforskrift eða hreyfingarplani. Pess vegna er oft stuðst við athuganir aftur í tímann (historical experiments) sem er ekki eins sterk sönnun á orsakasambandi áhættupáttar og sjúkdóms eins og slembiröðuð rannsókn. Pess vegna verða margir til að draga í efa niðurstöður rannsókna 1 lýðheilsuvísindum. ${ }^{25,46,49}$ Framskyggnar rannsóknir, eins og Hóprannsókn Hjartaverndar á Reykjavíkursvæðinu, eru hins vegar taldar gefa mun sterkari vísbendingar um samband áhættupátta við sjúkdóma en afturskyggnar rannsóknir. Margar sambærilegar rannsóknir eru til víða um heim og pegar flestar rannsóknir hafa komist að sömu niðurstöðu hefur pað leitt til stjórnvaldsaðgerða sem hafa skilað miklum árangri. Áhrif reykinga á nýgengi hjartasjúkdóma og lungnakrabbameins eru kannski skýrustu dæmin um nýtingu slíkra rannsóknarniðurstaðna.

\section{Niðurlag}

Langvinnir sjúkdómar eru stærsta ógn við heilbrigði, framfarir og hagvöxt um allan heim á komandi árum. Mestur hluti pessara sjúkdóma er áunninn vegna óheppilegra lifnaðarhátta sem við höfum tamið okkur á síðustu 50 árum. Miklum árangri má ná með einföldum og ódýrum stjórnvaldsaðgerðum sem takmarka nokkra vel pekkta áhættupætti í umhverfi okkar. Auka parf áherslu á pað að viðhalda heilbrigði í stað pess að meðhöndla einungis sjúkdóma enda er pað mun ódýrari og áhrifaríkari nálgun til bættrar lýðheilsu. Hér hafa læknar og annað heilbrigðisstarfsfólk mikilvægu hlutverki að gegna við að upplýsa heilbrigðisyfirvöld um orsakir sjúkdóma og ekki síður hvaða inngrip eru áhrifamest til pess að koma í veg fyrir próun langvinnra sjúkdóma í samfélaginu. Мeð pví að sameina krafta fagaðila, stjórnmálamanna og almennings sem láta sig málið varða munum við ná árangri í baráttunni við pá langvinnu sjúkdóma sem ógna heilsu komandi kynslóða. 


\title{
Heimildir
}

1. WHO. Gaining Health. The European Strategy for Prevention and Control of Non-communicable diseases. WHO, Genf 2006.

2. WHO. Mortality and burden of disease estimates for WHO Member States in 2004. World Health Organization, Genf 2009.

3. Yusuf S, Hawken S, Ounpuu S, Dans T, Avezum A Lanas F, et al. Effect of potentially modifiable risk factors associated with myocardial infarction in 52 countries (the INTERHEART study): case-control study. Lancet 2004; 364: 937-52.

4. Rose G. Sick individuals and sick populations. Int J Epidemiol 2001; 30: 427-32

5. World Economic Forum. Global risks 2011, 2011

6. Aspelund T, Gudnason V, Magnusdottir BT, Andersen K, Sigurdsson G, Thorsson B, et al. Analysing the large decline in coronary heart disease mortality in the Icelandic population aged 25-74 between the years 1981 and 2006 PLoS One 2010; 5: e13957.

7. Björck L, Rosengren A, Bennett K, Lappas G, Capewell S. Modelling the Decreasing Coronary Heart Disease Mortality in Sweden between 1986-2002. Eur Heart J 2009; 30: 1046-9.

8. Ford ES, Ajani UA, Croft JB, Critchley JA, Labarthe DR, Kottke TE, et al. Explaining the decrease in US deaths from coronary disease, 1980-2000. N Engl J Med 2007; 356: 238898.

9. Unal B, Critchley JA, Capewell S. Modelling the decline in coronary heart diesease deaths in England and Wales 19812000: comparing contributions from primary prevention and secondary prevention 2005. BMJ 2005; 331: 640 .

10. OECD (2010). Health at a Glance: Europe 2010. OECD Publishing 2012

11. Beaglehole R, Bonita R, Horton R, Adams C, Alleyne G, Asaria $\mathrm{P}$, et al. Priority actions for the non-communicable disease crisis. Lancet 2011; 377: 1438-47.

12. Barton P, Anndronis L, Briggs A, Lindsay WR, McPherson $\mathrm{K}$, Capewell S. Effectiveness and cost effectiveness of cardiovascular disease prevention in whole populations: modelling study. BMJ 2011; 343: d4044.

13. Orton L, Lloyd-Williams F, Taylor-Robinson, O'Flaherty $\mathrm{M}$, Capewell S. The use of research evidence in public health decicion making processes: systematic review. PLoS One 2011; 6: e 21704

14. Strazzullo P, D’Elia L, Kandala N-B, Cappuccio FP. Salt intake, stroke, and cardiovascular disease: a meta-analysis of prospective studies. BMJ 2009; 339: b45676.

15. Cappuccio FP CS, Lincoln P, McPherson K, Policy options to reduce population salt intake. BMJ 2011; 343: d4995.

16. He FJ, MacGregor G. Effect of modest salt reduction on blood pressure: a meta-analysis of randomized trials. Implications of public health. J Hum Hypert 2002; 16: 76170 .
17. Bibbins-Domingo K, Chertow GM, Coxson PG, Moran A, Lightwood JM, Pletcher MJ, et al. Projected effect of dietary salt reductions on future cardiovascular disease. $\mathrm{N}$ Engl J Med 2010; 362: 590-9.

18. O'Flaherty M, Flores-Maeo G, Nnoaham K, LloydWilliams F, Capewell S. Potential cardiovascular mortality reductions with stricter food policies in the United Kingdom of Great Britain and Northern Ireland. Bull World Health Organ 2012; 90: 522-31.

19. Kahneman D, Tversky A. Prospect theory: An analysis of decision under risk. Econometrika 1979; 47: 263-91.

20. Mozaffarian D, Katan MB, Ascherio A, Stampfer MJ Willett WC. Trans Fatty Acids and Cardiovascular Disease N Engl J Med 2006; 354: 1601-13.

21. Stender S, Dyerberg J, Bysted A, Leth T, Astrup A. A trans world journey. Atheroscler Suppl 2006; 7: 47-52

22. Mozaffarian D, Aro A, Willett WC. Health effects of transfatty acids: experimental and observational evidence. Eur $\mathrm{J}$ Clin Nutr 2009; 63 Suppl 2: S5-21.

23. Cesaroni G, Forastiere F, Agabiti N, Valente P, Zuccaro P, Perucci CA. Effect of the Italian smoking ban on population rates of acute coronary events. Circulation 2008; 117: 1183-8.

24. Lightwood JM, Glantz SA. Declines in acute myocardial infarction after smoke-free laws and individual risk attributable to secondhand smoke. Circulation 2009; 120: 1373-9.

25. Meyers DG, Neuberger JS, He J. Cardiovascular effect of bans on smoking in public places: a systematic review and meta-analysis. J Am Coll Cardiol 2009; 54: 1249-55.

26. Mozaffarian D, Capewell S. United Nations' dietary policies to prevent cardiovascular disease. Modest diet chances could halve the global burden. BMJ 2011; 343: d5747.

27. UN. Political Declaration of the High-level Meeting of the General Assembly on the Prevention and Control of Noncommunicable Disases United Nations General Assembly, sixty-sixth session. United Nations, New York 2011.

28. WHO. Framework Convention on Tobacco Control In: Organization WHO, ed. Geneva, 2003: Resolution WHA56.1.

29. Hamer M, Chida Y. Active commuting and cardiovascular risk: a meta-analytic review. Prev Med 2008; 46: 9-13.

30. Sofi F, Capalbo A, Cesari F, Abbate R, Gensini G. Physical activity during leisure time and primary prevention of coronary heart disease: an updated meta-analysis of cohort studies. Eur J Cardiovasc Prev Rehabil 2008; 3: 24757.

31. Thaler R, Sunstein C. Nudge. Improving decisions about health, wealth and happiness. Penguin Books 2009

32. Cohen DA, Babey SH. Candy at the Cash Register - A Risk Factor for Obesity and Chronic Disease. N Engl J Med 2012; 367: 1381-3.
33. Thorgeirsson T, Kawachi I. Behavioral Economics. Merging Psychology and Economics for Lifestyle Interventions. Am J Prev Med 2013; 44: 185-9.

34. Kahneman D. Thinking, fast and slow. Farrar, Straus and Giroux 2011.

35. Wansink B, van Ittersum K, Painter JE. Ice Cream Illusions. Bowls, Spoons, and Self-Served Portion Sizes. Am J Prev Med 2006; 31: 240-3.

36. Wansink B, Just D, Payne CR. Mindless eating and healthy heuristics for the irrational. Am Econ Rev 2009; 99: 165-9.

37. Wansink B. From mindless eating to mindlessly eating better. Psychol Behav 2010; 100: 454-63.

38. Downs JS, Loewenstein G. Wisdom. Strategies for promoting healthier food choices. Am Econ Rev 2009; 99: 159-64.

39. Lowenstein G, Brennan T, Volpp KG. Asymmetric paternalism to improve health behaviours. JAMA 2007; 298: 2415-7.

40. Arnett JJ. Optimistic bias in adolescent and adult smokers and nonsmokers. Addict Behav 2000; 25: 625-32.

41. MacKay S. Legislative solutions to unhealthy eating and obesity in Australia. Public Health 2011; 125: 896-904.

42. Stuckler D. Population causes and consequences of leading chronic diseases: A comparative analysis of prevailing explanations. Milbank Q 2008; 86: 273-326.

43. Jha P, Peto R, Zatpmslo W, Boreham J, Jarvis MJ, Lopez AD. Social inequalities in male mortality, and in male mortality from smoking: indirect estimation from national death rates in England and Wales, Poland and North and North America. Lancet 2006; 368: 367-70.

44. Vilhjálmsson R. Frestun læknispjónustu meðal Íslendinga: Umfang og skýringar. Læknablaðið 2011; 97: 529-34.

45. Alwan A, MacLean DR, Riley LM, d'Espaingnet ET Mathers CD, Stevens GA, et al. Monitoring and surveillance of chronic non-communicable diseases: progress and capacity in high-burden countries. Lancet 2010; 376: 1861-

46. Zatonski WA, Willet W. Changes in dietary fat and declininc coronary heart disease in Poland: population based study. BMJ 2005; 331: 187-8.

47. O’Kelly S, Andersen K, Capewell S, Rydén L. Bringing prevention to the population: an important role for cardiologists in policy-making. Eur Heart J 2011; 32: 1964-7.

48. Capewell S, Andersen K. The ESC goes global. Policies to prevent all chronic diseases. The alarming increase in global NCDs is stimulating efforts to tackle the burden on national levels. Eur Heart J 2011; 32: 2333-40.

49. Capewell S, O'Flaherty M. Can dietary changes rapidly decrease cardiovascular mortality rates? Eur Heart J 2011; 32: 1187-9.

\section{ENGLISH SUMMARY}

\section{Health policy interventions: The pathway to public health}

\author{
Andersen $\mathrm{K}^{1}$, Gudnason $\mathrm{V}^{2}$
}

Chronic non-communicable diseases (NCDs) are currently the main cause of premature death and disability in the world. Most of these NCDs are due to unhealthy lifestyle choices i.e. tobacco, unhealthy diet, lack of physical exercise and alcohol consumption. Studies have shown that health policy interventions aiming at improving diet and physical activity and reducing tobacco consumption are inexpensive, effective and cost saving.
In this paper we address the political health policy interventions that have been shown to improve public health. We discuss some of the theories of behavioral economics which explain the processes involved in our every-day choices regarding lifestyle and diet.

Correspondence: Karl Andersen, andersen@landspitali.is

Key words: lifestyle, policy intervention, behavioral economics.

${ }^{1}$ Cardiovascular Research Center Landspitali University Hospital Faculty of Medicine, University of Iceland IS-101 Reykjavik, Iceland. 2lcelandic Heart Association Reseach Institute Faculty of Medicine, University of Iceland IS-200 Kópavogur, Iceland 